\title{
Book Review. Uricska Erna's COVIDICTIONARY: Words and Phrases Related to the Global Pandemic
}

\author{
NÓRA BARNUCZ \\ Affiliation: University of Public Service Ludovika, Budapest, Hungary \\ Researcher of ICT MasterMinds Research Group \\ Email: barnucz.nora@uni-nke.hu
}

\begin{abstract}
This unique work in its subject matter, genre and language was prepared during the first wave of the coronavirus epidemic. The theoretical background of the author's research work is perfectly adjusted to Patyi's "university triangle" model ("Nemzeti Közszolgálati Egyetem, Intézményfejlesztési Terv 2015-2020," n.d.), which basically illustrates the functioning of a university in a triple system of the activities "researcheducation-curriculum development," and Paavola and Hakkarainen's trialogical model (2005), which-through the competence of cooperation-provides an opportunity to develop students' creativity, to keep their motivation at a high level, to develop competencies required by the labour market, and to implement experiential teaching-learning. A questionnaire survey was used with closed and open questions among students who have been learning English for law enforcement at the University of Public Service Faculty of Law Enforcement (hereinafter: UPS FLE) using the corpus-based dictionary method. The author's acquaintances registered on Facebook social media platform were also involved in the research. The 96-page collection of words and phrases based on the theoretical background involves 403 English words, word phrases, neologisms and their definitions related to the coronavirus epidemic and COVID-19 situation during the first wave.
\end{abstract}

Keywords: covid dictionary, social networking sites, English for law enforcement, university triangle, trialogical learning

The author is a doctoral student at the Doctoral School of the Sociology and Communication Science, Corvinus University of Budapest. Her research interests include the study of digital communication on the social network sites of the English, the American, and the Hungarian law enforcement organizations. 
The author's research activities are not limited to theoretical and empirical research. This is evidenced by the unique-in its subject matter, genre and language-work that was completed by the author during the first wave of the worldwide coronavirus epidemic. The basic idea of the collection of the English monolingual words and phrases (hereinafter: collection) was also inspired by Ágnes Veszelszki's Quarantine Dictionary (2020a) in Hungarian, who is the author's supervisor, an Associate Professor, the Head of the Department of Communication and Media Studies at Corvinus University of Budapest. The dictionary was based on the observation that the coronavirus epidemic in the early 2020 had led to the emergence of a number of new terms in the language or to the revival of words that had been previously rarely used (Veszelszki, 2020a). The researcher explored the effects of the coronavirus on the Hungarian language in her latest research. The phenomenon that language-especially vocabulary-responds immediately to crises in all areas of life, such as the pandemic caused by the coronavirus, is not new (Veszelszki, 2020b). These professional background factors and inspirations were enough for Erna Uricska to think further the basic idea in the midst of the current pandemic, create an object with the purpose of the practical implementation of community teaching and learning and research, which in addition is considered a novelty in its own genre, and is also compatible with the following scientific theoretical models.

Patyi's "university triangle" model ("Nemzeti Közszolgálati Egyetem, Intézményfejlesztési Terv 2015-2020," n.d.)-which was explained in detail in a co-authored work of Patyi and Barnucz (2020)-fits perfectly to the theoretical background of the collection. The model presents the university operations, namely the scientific work (research), the education (preparation) and the curriculum development as a system of activities that are simultaneously performed, with respect to and in coordination with each other. Paavola and Hakkarainen's (2005) trialogical model can be adapted well and updated for the creation of the dictionary, in which students collaboratively develop a knowledge object during the teaching-learning process. Thus, it creates an opportunity to develop the students' creativity, keep their motivation at a high level, develop competences required by the labour market, and implement experiential teaching-learning (Uricska, 2020a). In addition to the theoretical models, the adaptation of a practical model of language learning can be mentioned like the model of metacognitive strategies (Barnucz \& Uricska, 2020). Its particular importance is the vocabulary development in language learning, while communicating in the target language. 
The author wanted to adapt the collection to the activities of the university triangle: on the one hand, to the scientific research on the definitions of each term; on the other hand, to produce knowledge based on the university curricula. Finally, the researcher pays special attention to the use of the dictionary in seminars by students. In line with Patyi's university triangle model and Paavola and Hakkarainen's trialogical teaching and learning model together give the university quality, and the researcher has fulfilled it with her present work. A questionnaire survey was used with closed and open questions among students who had been learning English for law enforcement at UPS FLE using a corpus-based dictionary method, more specifically a word survey. The students, following the request of their instructor, collected new terms related to the coronavirus epidemic, distance learning, and their future profession. Furthermore, the author extended the research to her acquaintances on Facebook, and a lot of them also joined in word collection thus implementing a kind of community research and teaching-learning. As a result, the research became well-known internationally, as her acquaintances in the United States, Germany, the United Kingdom and Luxembourg participated in the research and enriched the collection with a number of terms. The aim of the author was to achieve internationalization through social media, which is one of the indispensable platforms for education and research in the twenty-first century. Overall, the author has put the trialogical model of Paavola and Hakkarainen (2005) into practice with excellent research skills, as the model is well adapted to online and offline knowledge creation activities, where the focus is not only on the individual and the community, but also on a process in which the participants of knowledge creation collaborate to create a shared knowledge object (community learning).

The relevance of the language learning metacognitive strategy model (Barnucz \& Uricska, 2020, 2021) shows that there are often breakpoints in the development of the language learners' communication, which can be improved with the help of the model. In a higher education (academic) context, the prevalence of memory-based, cognitive and metacognitive strategies is the most important among students learning a (professional) foreign language, as well as the fact that cognitive schemes of professional knowledge also facilitate the acquisition of professional language use and vocabulary (Jakusné, 2014). The metacognitive model consists of four processes that are interdependent rather than strictly sequential: planning, monitoring, problem solving and evaluating. When applying the model, the instructor's responsibility is to decide which strategic step is prioritized for the processing of the learning material. 
The scientific standard of the collection is also sufficiently supported by the references. The English and Hungarian articles as well as the websites listed in the bibliography provide inspiration for the preparation of the dictionary. The international themes of the literature listed raise the quality of the research even further. The bibliography at the end of the collection follows a sophisticated and consistent style. From the author's final reflection on the outside cover of the collection, we learn that the purpose of the dictionary, in addition to the practical implementation of community teachinglearning and research, is to express one's respect to frontline workers. The author also confirms this with the image of a nurse-wearing a mask while working in health care-on the outside cover of the collection. In the short summary at the back of the volume, the author provides information about the content of the work, expresses her gratitude to the colleagues, as well as to her closest colleagues working at UPS.

Based on this theoretical background, the 96-page collection contains 403 words, word structures, phrases and neologisms, and their definitions related to the coronavirus epidemic and quarantine situation that were most commonly used in English during the first wave of the epidemic. A good example of this is the neologism "smizing," which is an excellent way to capture the non-verbality of communication, since in the current epidemic situation, it is only our eyes that are uncovered and what we can express our feelings with. The dictionary also includes several other neologisms, such as "coronacation," "coronacoaster," "quaranteam," etc., which gives the novelty of the collection. All these have been supplemented by indicating the class of words, word structures and expressions, their synonyms and, in some places, by adding example sentences to some items. Most of the word structures are concentrated around the terms used by frontline workers, mainly in the fields of law enforcement and health care. The researcher has also taken care of the professional and linguistic proofreading of the word and phrase collection. The professional proofreading of the dictionary was performed by Judit Borszéki, Assistant Professor at the Department of Foreign Languages for Specific Purposes of the FLE, UPS, while the language proofreading was done by Josephine Moleon, a native speaker and researcher. The editor of the dictionary was Katalin Molnár, Associate Professor at the Department of Behavioural Sciences, of the FLE, UPS. 
In line with all the research methodology, the dictionary can be useful for researchers working in communication studies and/or social media research (Uricska, 2020b, 2020c), while from the linguistics viewpoint it can serve as an excellent teaching material or supplementary material for English teaching training; and as it is a niche, the dictionary can also be useful for teachers and students of law enforcement and health care.

\section{References}

Barnucz, N., \& Uricska, E. (2020). Innovatív nyelvtanulási módszerek és módszertan a rendészeti szaknyelvi képzés vizsgálatában. Előtanulmány egy vizsgálathoz. Új Pedagógiai Szem/e, 70(9-10), 53-63. https://bit.ly/2NIAToc

Barnucz, N., \& Uricska, E. (2021). Kiterjesztett valóság és közösségi oldalak alkalmazása a nyelvoktatásban különös tekintettel a rendészeti szaknyelvre. Rendvédelem, 10(2), 4-48. Brown, H. D. (1994). Teaching by principles. Prentice Hall.

Jakusné Harnos, É. (2014). A tudásszerveződés formáinak szerepe a szakmai nyelvhasználatban. In Zs. Bocz (Ed.), Porta Lingua (pp. 245-254).

Kelemen, K., \& Talabér, J. (2014). „Szavak nélkül a nyelv halott”-A szóbeli kommunikáció prioritása az idegennyelv-oktatásban. In J. Torgyik (Ed.), Sokszínú pedagógiai kultúra (pp. 420-426). https://bit.ly/3ati1mc

Nemzeti Közszolgálati Egyetem, Intézményfejlesztési Terv 2015-2020. https://bit.ly/2WFes/4 Paavola, S., \& Hakkarainen, K. (2005). The knowledge creation metaphoran emergent epistemological to learning. Science and Education, 14(6), 535-557. https://doi.org/10.1007/s11191-004-5157-0

Patyi, A., \& Barnucz, N. (2020). A közszolgálati és rendészeti felsőoktatás néhány időszerű kihívása. Új Magyar Közigazgatás, 13(4), 1-12.

Uricska, E. (2020a). Rendészeti közösségi oldalak alkalmazása a szaknyelvoktatásban. Educatio. 29(4), 653-662.

Uricska, E. (2020b). Közösségi rendészet-közösségi média. Elméleti háttér és a rendészeti digilektus fogalmának bevezetése. Magyar Rendészet, 20(2), 153-168. https://doi.org/10.32577/mr.2020.2.8

Uricska, E. (2020c). Proper interactive communication of the police as a(n e-)trust-building strategy. Introducing the term policing digilect. Kosice Security Revue, 10(2), 185-195.

Uricska, E. (2021). COVIDICTIONARY: Words and phrases related to the global pandemic. Rejtjel Kiadó.

Veszelszki, Á. (2020a). Karanténszótár. Virális tartalom. Budapest: Inter - IKU.

Veszelszki, Á. (2020b). Karanténszótár. Corvinus Podcast. https://bit.ly/2ZZeLb| 